\title{
Supporting youth Employment through Vocational Training Programs in Nepal
}

\author{
Kushmakar Bhatta, PhD \\ Senior Trainer \\ Training Institute for Technical Instruction (TITI) \\ Sanothimi, Bhaktapur ,Nepal \\ Corresponding Email: k2bhatta@gmail.com
}

\begin{abstract}
The effect of globalization on human capital development is decisive. A country that lacks the means to compete in global market is often left behind. A key contributor in this regard is the knowledge, skills and positive attitude of the workforce. Education and skills therefore are the driving forces of social development and economic growth of any country. The first Sustainable Development Goal (SDG) is to end poverty in all forms by 2030 and for that there is major focus on education and productive employment. SDG-4 focuses on people's access to modern and quality education, which also indicates the need of vocational education and trainings. Similarly, the SDG-8 is to promote sustained economic growth, higher levels of productivity and technological innovation which indicated the need of TVET for productive employment and economic growth. Therefore, employment level of the working age group people, its composition and the growth in employment opportunities appeared as the critical indicator of the development process in any economy. The present paper attempts to highlight the positive effects that was contributed by the Vocational Education and Training (VET) programs in socio-economic development of large number of disadvantaged and unemployed population of Nepal. Primary data and information collected from the purposively sampled respondents- 405 VET graduates who after training are employed in their occupational sector. The study including field observation was conducted in 2016 to obtain qualitative information that helps to establish the relationship between vocational training and employment of the trained youth. The finding of this study revealed that VET plays positive role in employment and income growth. However, it concludes with the recommendation that the participants need post training support to become a functional VET and to get a sustainable and decent employment in the labor market.
\end{abstract}

Keywords: Vocational Education, Post Training Support, Employment, Income, Poverty.

\section{Introduction}

Youth unemployment is a serious problem all over the world. Recent data of ILO (2016) showed that, there are 199.4 million jobless people in the world. 
The youth that faced the greatest problems were the early school leavers. As documented in a large body of research, early school leavers have experienced a much less successful transition to work compared to those who completed year 12 . The 21 st century has brought profound and fundamental changes to economics, technology, politics, culture, morals, social values and ethics. As a driving force globalization has both expanded the opportunities and added challenges to individuals as well as to the organizations; some countries or some individuals benefitted from the increasing competition and trade expansion while others have suffered from the increased unemployment and underemployment. (Uddin, 2008). The economy becomes more productive, innovative and competitive both in quality and quantity through the existence of human potential. (Stormback, 2010). Limited attention has been given to the relation between the labor market and VET through empirical researches, but in the labor economics, there is a study and estimation of casual effect of education on earning. Stromback further emphasizes the relationship between education and earnings stating that it is the most intensively studied issue in labor economics.

\section{Individual and Societal Returns of Vocational Education}

Education affects not only the person being educated but also the whole community starting from his/her family. Producing a number of educated, skilled and efficient people is contributing to build a prosperous society. The following figure shows the individual and social returns of the vocational education and trainings.

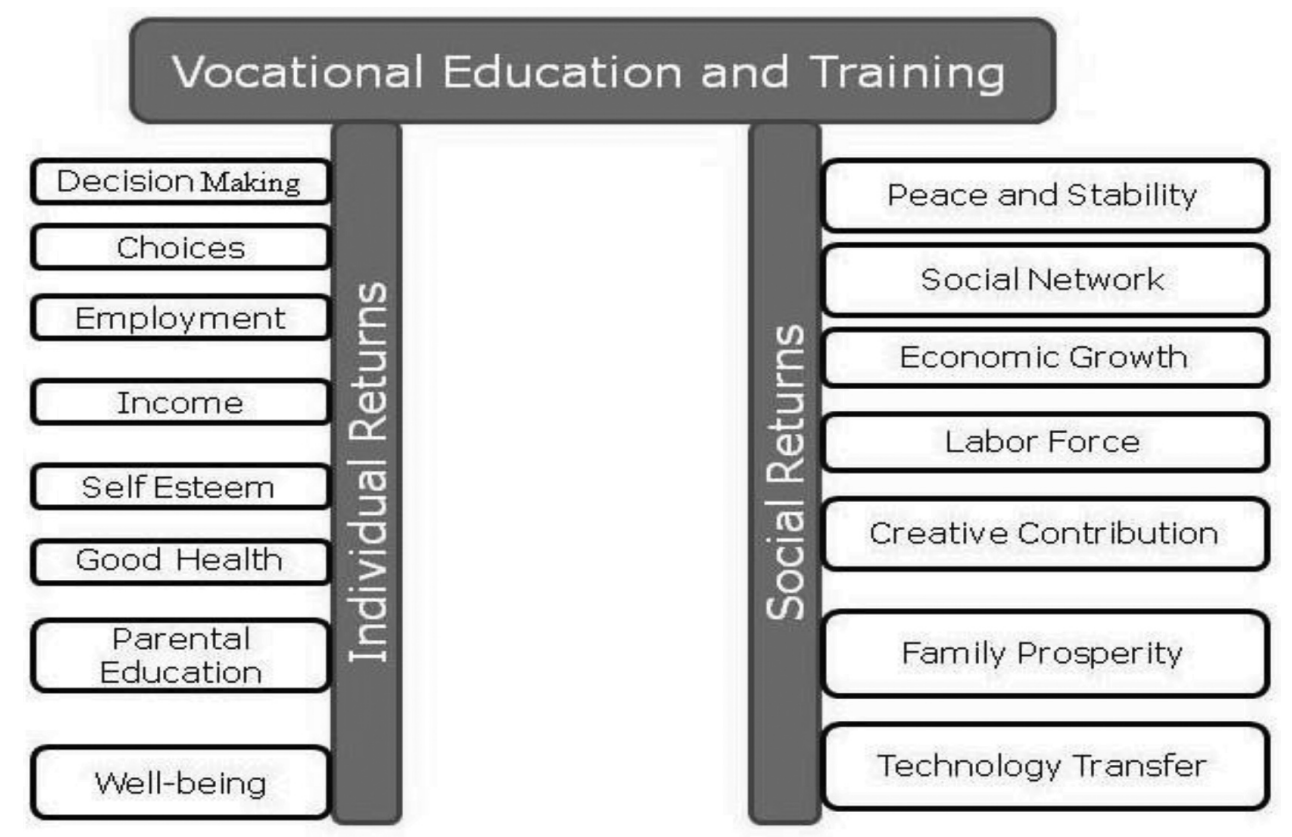

\section{Figure-1: Individual and Social Returns of Education}

The above figure proposes that education contributes to reduce poverty through direct (income) and indirect (externalities) channels. Based on labor requirements and a country's development status, it is said that primary education is most important for economic growth in low-income developing countries, secondary education for middle-income developing countries and tertiary education for rich countries (Pervez, 2011). As Plato has mentioned "The direction in which education starts a man will determine his/her future in life" is contextual because youth equipped with quality skills, knowledge and attitude will 
contribute to individual as well as social development. Nepal is undergoing a holistic transition toward a secular republic. This represents a window of opportunity for the country to further reduce poverty, increase the income of the bottom 40 percent and peruse its ambitious agenda of inclusive growth and accountability in service delivery (Bank, 2020). Underdeveloped countries like Nepal, where the poverty index is high $(21.6 \%)$, on one side, more than 500 thousand active youths enter into the Nepalese labor market every year and on the other side, the country hardly has the capacity to train 100 thousand youth per year (CTEVT, 2076). The data shows that there is a large gap between demand and supply of labor force. The growth of skilled human resources and creation of employment is not satisfactory. More than 1,000 youths leave the country every day. Around 4.3 million youth working in foreign employment are categorized as 1.5 percent skilled, 23 percent semi-skilled and 75.5 percent unskilled (GON, 2017). Vocational education and training can be instrumental to the socio-economic development. The research and studies on VET programs helps support the Nepalese youth to create employment and earn for their living. In this context, a field level study can provide an insight to understand the contribution of VET programs in Nepal. Previous studies of international development agencies have concluded VET program as one of the most possible solutions to the unemployment problem faced by the large number of youths. The VET programs can help the youths by opening the doors of earnings by engaging in self, wage and foreign employment, if there is strong provision of post training support services (World Bank, 2016).

\section{Purpose of the Study}

TVET programs are in priority of the Government of Nepal. The constitution of Nepal (2072) has declared education as a fundamental right; skill development is highly focused in the development plans, policies and strategic plans. In this regard, the role played by this education sub-sector is to be studied. The purpose of this paper is to examine the post training services provided by the TVET providers which support the TVET graduates in employment, earning and poverty alleviation. More specifically, the study sought to test the following hypothesis:

\section{$\mathrm{H}_{0}$ : Vocational education and training programs are not contributing to poverty reduction/income generation.}

The intention of the study is to explore whether the VET has a considerable impact to the young population of Nepal on the employment and earning despite their low level of general education. This study will benefit Council for Technical Education and Vocational Training (CTEVT) and other TVET implementing agencies of Nepal by focusing on employment generation through a functional, TVET that emphasizes practical knowledge, skills and selfreliance for employability after completing a certain process of VET.

\section{Study Method}

The study employed survey for Vocational Education and Training (VET) graduates trained from different institutions were purposively selected from the list of the VET graduates and interview questionnaires were sent to them. Apart from the questionnaire, some field survey was also administered for the qualitative data on role played by VET in employment, income and socio-economic development.

\section{Findings}

In support to the research statement, "VET programs supporting the Nepalese youth to create employment and earn for their living", some supporting questionnaire were asked to the graduates to gather information like their employment status, earning and income before joining VET, employment status after vocational training, income after graduation in vocational education and other indirect effect of education in the graduates like self esteem and support in children's education and health. All of the supportive components attempted to find out the relation between VET and poverty alleviation. Income and earning level of the graduates for both prior to and after the training were examined. Similarly, they 
were also asked about the support they received from the training providers regarding job placement and the finding in regard with employment and income is assertive whereas the post training support they received was inadequate.

The expected outcomes of vocational education and training programs included effects and benefits to the beneficiaries who are generally poor, women and other disadvantaged group. These effects on the graduates refer to the increments in both cognitive and occupational skills that are required in the workplace and that contribute to developing the career of each individual graduate. Similarly, VET providers also benefitted from the quality programs owing to increased sustainability of their business and increased numbers of trainees. Industries benefitted from the supply of capable work force who were readily available for their industries. The societies benefited from this since it increased economic productivity, higher taxable earnings, peace and prosperity in the country.

Employment opportunities, earnings and socioeconomic development of the graduates are considered as the most essential criteria to measure the effectiveness of VET programs. The labor market is dynamic, and it is changing. VET programs are expected to respond to such changing labor market in order to meet the effectiveness criteria. The study deals with the question if the skills training programs meet the needs and requirements of the changing labor market. Unless and until the graduate's competencies match with the demand of the employers, meaningful employment cannot be expected in the labor market. Unemployment of trained graduates does not emerge only due to students'/trainees' inadequate aptitude but also largely due to the mismatch of training contents and competencies required in the job market. Therefore, the need for periodically checking through research and impact studies arises to ascertain the graduate's absorption in the labor market, their earning levels, and employers' satisfaction and to match the demand and supply of trained skilled graduates.

\section{Hypothesis Test}

H0: Vocational education and training programs are not contributing to poverty reduction/income generation.

Since there are many definitions of poverty, for a particular purpose, here in this study, income level is taken as the proxy of poverty which also helps to explain the maximum number of criteria explaining poverty. Looking at the mean value of incomes of the participants before participating in the training program and income from the job after attending the training, it is clear that trainees were able to earn more after attending the training program. For evidence, the mean data are presented in the table1 below.

Table 1

Group Statistics of Income (Income prior and after the training)

\begin{tabular}{cccccc}
\hline \multicolumn{2}{c}{ Period } & $\mathrm{N}$ & Mean & Std. Deviation & Std. Error Mean \\
\hline Income & Before & 178 & 5275.28 & 2702.28 & 202.54 \\
\cline { 2 - 6 } & After & 368 & 9173.91 & 2302.04 & 120.00 \\
\hline
\end{tabular}

From the above table it is clear that, the mean income of trained graduates is increased by about 74 percent after attending the vocational education and training program. That clearly indicated the changes in living standard caused by the training and its effect, which helped to get employment with higher level of income.
Only looking at the mean values, it might be too early to decide if the training programs were successful in generating income, i.e. to reduce poverty. So, we further take the help of t-test for significance of difference between two means and the table- 2 below clearly presents the result. 
Table 2

Independent Samples Mean Test (pre and post training income)

\begin{tabular}{|c|c|c|c|c|c|c|}
\hline & & $\begin{array}{l}\text { Leven } \\
\text { Equalit }\end{array}$ & inces & t-test fo & Equality of $\mathrm{Me}$ & \\
\hline & & F_stat & & & & \\
\hline \multirow{4}{*}{ Income } & \multirow{2}{*}{$\begin{array}{l}\text { Equal variances } \\
\text { assumed }\end{array}$} & \multirow{4}{*}{$\begin{array}{l}5.14 \\
(.024)\end{array}$} & $\mathrm{t}$ & $\mathrm{df}$ & Sig. (2-tailed) & Mean Difference \\
\hline & & & -17.50 & 544 & 0.00 & -3898.63 \\
\hline & Equal variances & & & & & \\
\hline & not assumed & & -16.56 & 304.95 & 0.00 & -3898.63 \\
\hline
\end{tabular}

Here p-value for F-stat is less than 0.05 , so according to the Levene's Test of Equality of Variance, we should assume that the group variances are not equal and there is a need to select the second row for ttest analysis. Here, the obtained absolute t-stat is equal to 16.560 with 305 degree of freedom, and the t-stat is significant at 0.05 percent level. Thus we can reject the null hypothesis that there is no difference in the income level for before and after the training program.

Further chi- square test is performed to see whether the training programs and income earned after the training is associated or not. Calculated test statistics are presented in table below.

Table-3

Chi -Square Tests (Association between Employment and Income)

\begin{tabular}{lccc}
\hline & Value & df & Asymp. Sig. (2-sided) \\
\hline Pearson Chi-Square & 410.18 & 8 & 0.000 \\
Likelihood Ratio & 283.34 & 8 & 0.000 \\
Linear-by-Linear Association & 122.29 & 1 & 0.000 \\
\hline N of Valid Cases & 405 & & \\
\hline
\end{tabular}

From test statistics and probability it can be concluded that the null hypothesis of no association between training and income generation/poverty alleviation can be rejected. The data further concludes that training programs are supporting in income generation and contributing to reduce the poverty of the VET graduates.

Placement and counseling support was regarded as an integral part of the vocational education and training. According to the qualitative data received there was substantial need to facilitate the graduates through job searching, applying, communication, interview facing, professional attitudes etc. which are the related soft skills to be imparted. In some occupations for the wage as well as self-employment, post training supports were more required than in other occupations. However, such adequate services contribute to employing the graduates. In this study, the graduates were asked about the support they received from the VET providers and the contributing factors that helped to get the job in their occupational area. Out of the total surveyed employed graduates, 51.1 percent expressed that the service providers supported them by providing information about the job and job market. More than 51 percent of the respondents said that the institutions only provided information about the job. Similarly, 
22.5 percent of the respondents responded that they were supported by the training providers on how to find a job, 7.7 percent of them responded that they received information about the financial institution as a post training support. Out of the total respondent graduates, 12.1 percent have totally denied receiving any support from the service provider as post training service. A very few number of the respondents $(6.7 \%)$ were supported by the training providers on job placement. This clearly indicates that in addition to the skill and knowledge, post training support services to the trained graduates are essential for their placement in job.

VET training is instrumental for employment, earning and it has contributed positively in socio-economic change. However, the role of the VET providers before training, during training and post training phase should be very crucial. Since majority of the respondent graduates had commented that the training providers support by providing job related information was good but only information was inadequate to get employment. Similarly, the qualitative information received from the educationist, employers and graduates also has argued that the VET is instrumental in getting job.

\section{Discussion}

To support this study, there is longstanding evidence that the effects of education on productivity are much more marked when there is a dynamic, supportive environment surrounding schools. However, most of the developing countries have highly focused education and training system as a solution to unemployment/under employment and poverty reduction (Palmer, 2011). Education is a powerful tool for production, economic growth and poverty reduction. Changing technology and economic reforms are creating dramatic shifts in the structure of economies, industries, and labor markets throughout the world (ADB, 2009). The rapid increase in knowledge and the pace of changing technology raised the possibility of sustained economic growth with more frequent job changes on individuals' lives. This shift in paradigms has created two key priorities for education: i) meeting demands for adaptable workers, who can readily acquire new skills and ii) support the lifelong learning and expansion of knowledge. Similarly, Technical and Vocational Education and Training (TVET) in specific, has two purposes: i) to prepare individuals for gainful employment and ii) to meet skilled human resources need for national development. There is also a kind of debates about skill, vocation and poverty. A skill has a positive relation with employment creation and employment and earning anticipated reducing poverty (Emilia, 2012). Studies and investigations have showed that growth of income affects poverty negatively. In these studies income was found to grow for all segments of the population and, as a result, poverty incidence fell. The study of the Goh and Zhu (2009) has quantified the real contribution of education to economic growth concluding that education has always been considered a dominant tool for reducing poverty and inequality through productivity enhancement, which is also a key factor in sustainable development (Donald, 2008). A study finding of Levine described that although, total factor productivity relates to labor, land and capital, the role of labor productivity is more important than all other factors of production. Education and skill promotes labor productivity and consequently, labor productivity positively influences the productivity of other factors of production (Levine, 2000).

In most of the developing countries, Vocational Education and Training (VET) programs are being run with the objective of achieving rapid development by making the maximum use of productive labor through the development of entrepreneurship while bringing changes in the traditional production system. Since the VET programs implemented in the country are aiming to contribute on reducing poverty, the study focused on assessing and examining the extent to which the graduates' had been engaged in productive activities after completing their training in the particular skill area. The employment and earning status of the VET graduates were examined in terms of self-employed or employed in domestic 
wages. These analyses confirmed that although employment opportunities and earnings level had been increased after the vocational education and training, it still needs to improve educational achievements for instance the training quality, duration of training and linkages with the financial institutions and job market. In order to achieve high level of productivity and to address the problem of youth unemployment and compete effectively with the growing economies, we need to ensure that more people acquire higher quality education and more skills. Similarly, CTEVT is responsible for managing the vocational education including setting course contents and curriculums in collaboration with the private sector. Several schemes and provisions like free-training, scholarships, collateral-free periodical loans after training can help to increase the participation of women and disadvantaged group in training and employment activities and fulfill the objective of poverty reduction (Uddin R. , 2008).

\section{Conclusion}

Vocational Education and Training (VET) programs are in priority of the Government of Nepal. There are several VET projects running in financial assistance of international agencies. The goal of all the projects is to strengthen the socio-economic status of unemployed youths, especially the women, Dalit and other Disadvantaged Group (DAG), who are deprived of higher education by providing them with vocational trainings and make them employable. Similarly, The programs run in the country in assistance with the international development organizations and the government's regular programs under CTEVT are found to be successful in fulfilling their objectives of upgrading the individual by making best use of the human resources through skilling, providing employment, making available the skilled human resources to the industry, increasing the productivity and contributing to the sustainable development activities. As discussed earlier, education plays a vital role in enhancing people's earning ability, increasing their self-esteem, contribute in improving family education, health and poverty alleviation. A robust quality assurance strategy will maintain the quality in TVET, for which post training support services are to be focused. Study on market demand, industries based curriculum, quality training, lifelong learning would have additional positive effect on employment of the youth.

\section{Recommendations}

TVET has a significant role in the international education and development agenda towards achieving the proposed sustainable development goals. The world now has more dependency on the knowledge and understanding based on the technology, scientific discovery and socio-economic development. Skills and competence acquired through appropriate training are found to be meaningful for both the individual and society. If the individual is benefited from employment and earning, then the nation will be benefited through the increase in productivity, income and image. Thus, the socio-economic prosperity of the country not only depends on the available natural resources but also on the appropriately trained human resources. The country needs efficient utilization of the trained human resources in the industrial and economic development process. VET programs are assumed to be strongly associated with the labor market transiting life towards work from school life. That is how the VET needs enabling young people to acquire employment related skills and attitudes. Although Education is not the only variable that determines school to work transition, but it is still the main key to open the door to work. Demographic and social characteristics such as gender, ethnicity and social classes give significant impacts on the work prospects and the life experiences of young people. However, empirical evidence shows that better educated youths are more likely to find decent employment and are less likely to be exposed to poverty. Quality education and skill development is essential for addressing the universal right to education, the right to work and contribute to reduce poverty. In Nepal's education system, relevance, access and quality are crucial to increase learner's employability, fulfill employer's skills needs and prepare the youth for green economies and societies. It is therefore suggested that the following measures 
if well articulated will mitigate the problems of the youth unemployment and help in poverty reduction.

a) Expansion of TVET programs both geographically and in occupational areas in access of the marginalized people based on market demand and self-employment opportunities.

b) Focus on industry based training, apprenticeship model closely collaborate with academy and industries facilitated by the government.

c) Encouragement to VET graduates with functional post training supports to increase self employment and job creation by assisting them with soft loans and/or micro-credit.

As indicated by the data, the major effects of the VET are that it had brought changes in the graduates' lives by increasing their health awareness, selfidentity, self-esteem and further education. There is a strong need to change the implementation modality for quality improvement. Emphasis on the practical aspect, adequate industry exposure through industryacademy collaboration of VET will help to produce competent, employable and productive youths of the nation' and labor force that will be self-reliant and easily adopted in the competitive labor market.

\section{References}

ADB. (2009). Poverty Reduction in Nepal: Issue, Findings and Approaches. Manila: Asian Development Bank.

Atchoarena, D. (2007). Vocational Education and Trainiing for Youth, pp. 1-4.

Benabou, R. (2003). Human Capital, Technical Change and the Welfare State. Journal of the European Economic Association, 522-532.

Berg, L. (2008). Poverty and Education. Paris: In ternational Institute for Educational Planning and International Academy of Education.

Central Bureau of Statistics. (2012). "National Population and Housing Census 2011 (National Report)". Kathmandu: Central Bureau of Statistics,Nepal. Retrived on 16 December, 2016.
CTEVT. (2011). A Profile of National Vocational Training Providers. Sanothimi, Bhaktapur: Research \& Information Division CTEVT.

CTEVT. (2015). Annual Report. Bhaktapur: Council for Technical education and Vocational Training (CTEVT).

CTEVT. (2076). Technical and Vocational Education and Training Integrated Report. Kathmandu: Ministry of Education, Science and Technology, Nepal.

Ellis, G. (1984). The Dimensions of Poverty. Social Indicators Research, 229-253.

Emila, H. (2012). Employment Strategy for Poverty Reduction. A Romanian Perspective. Procedia Social and Behavioural Sciences, 406-415.

Goh, Z. (2009). Income, Growth, Inequality and Poverty Reduction: A Case Study of Eight Provinces in China, 20 (3), 485-496. Beiging: China Economic Review.

GoN. (2017). Economic Survey, 2016/017. Kathmandu: Ministry of Finance, Government of Nepal.

Lesly, P. (2012). Reimagining the Purpose of VET Expending the Capability to Aspire in south African Further Education and Training Students. International Journal of Educational Development 32 (5), 643-653, DOI 10.1016/j. ijedudev.2012.01.008

Levine, W. E. (2000). It's not Factor Accumulation: Stylized Facts and Growth Models (Draft for Policy Research Group). Washington DC: World Bank.

Maclean, R. (2010). "Work Learning and Sustainable Development: Opportunities and Challanges. Bonn, Germany: UNESCO/UNEVOC.

Ministry of Education. (2015). Education Information. Kathmandu: Government of Nepal, Ministry of Education. 
Nworgu. (2004). Economy and Administration of Education in Nigeria, Nsukka. Nsukka: The University of Nigeria Press

Palmer, R. (2011). Beyond the Basics: Post basic Education, Training and Poverty Reduction in Ghana, Working Paper series No.4. Edinburg: Center of African Studies, University of Edinburg.

Pervez, K. (2011). The role of Education and Income in Poverty Alleviation: A Cross-Country Analysis. The Lahore Journal of Economics, 16: 1(Summer 2011): pp 143-172, 143-172.

Stormback, T. (2010). Earnings, Schoolings and Vocational Education and Training. Austrilian Journal of Economics, 241-263.

Uddin, R. (2008). The Role of Technical and Vocational Education in Poverty Reduction among Youths in Nigeria. Department of Vocational and Technical Education, Ambrose Alli University, Nigeria, 1-7.

World Bank. (2016). World Development Indicators 2016, Washington, The World Bank Group.

World Bank. (2020) Poverty and Shared Prosperiety 2020, Washington, The World Bank Group. 